\title{
DUPLICATION OF STRUCTURAL GENES FOR HEMOGLOBIN $a$ AND $\beta$ CHAINS IN MAN *
}

\author{
D. L. Rucknagel $\dagger$ and W. P. Winter \\ Department of Human Genetics \\ University of Michigan Medical School \\ Ann Arbor, Michigan 48104
}

The prevalence of multiple loci governing $\alpha$-chain synthesis in many other animal species has been adequately documented by earlier papers in this volume. Until rather recently the world of the human geneticist has been relatively simple, there being only one structural locus for each of the six types of polpeptide chains identified in man-the $a, \beta, \gamma, \delta, \epsilon$, and $\zeta$ chains. The work of Huisman and Schroeder and their colleagues ${ }^{1}$ assures us that there are at least two and perhaps four loci for the $\gamma$ chains of fetal hemoglobin; one or more of these have glycine at residue 136 and one or more have alanine. They further propose the existence of major and minor loci for each of these types. ${ }^{2}$

The possibility of two $H b_{\alpha}$ loci was first raised by Lehmann and Carrell ${ }^{3}$ who drew attention to the fact that heterozygotes for many $\alpha$-chain variants possess approximately $20 \%$ of the abnormal component, whereas heterozygotes for mutants of the $\beta$-chain structural locus possess 30 to $40 \%$ of the variant. The proportions of abnormal components present in published $\alpha$ - and $\beta$-chain mutants are shown in TABLE 1 . With some notable exceptions the proportion of abnormal $a$-chain variants vary between 15 and $35 \%$. A few variants fall below this range; for instance, $\mathrm{Hb}$ Ann Arbor, comprising 2 to $4 \%, 4 \mathrm{Hb}$ Torino, ${ }^{5}$ comprising 6 to $10 \%$, and $\mathrm{Hb}$ Bibba, ${ }^{6}$ comprising $11 \%$ of the total hemoglobin, are unstable and are probably denatured within the red cell. At the other extreme $\mathrm{Hb}$ G Philadelphia ${ }^{7}$ and $\mathrm{Hb}$ G Chinese $^{8}$ comprise as much as 40 to $50 \%$ of the total hemoglobin. The majority of the $\beta$-chain variants vary between 25 and $40 \%$ of the total hemoglobin. Again, variants such as Hb Genova, ${ }^{2}$ comprising $25 \%$, Hb Zurich, ${ }^{10}$ comprising $20-36 \%$ Hb Sabine, ${ }^{11}$ comprising $8 \%$ and $\mathrm{Hb}$ Köln, ${ }^{12}$ comprising $10-15 \%$ of the total hemoglobin, are unstable. However, in no less than sixteen $\alpha$-chain variants, the proportion of abnormal hemoglobin is $50 \%$ or more of the total hemoglobin.

Published data must be interpreted cautiously, however, because, aside from the variation imposed by instability, a wide variety of techniques were employed in the various studies. Moreover, since there is probably only a single $H b_{\beta}$ locus, in all likelihood the wide range of values among $\beta$-chain variants also reflects additional intrinsic differences in gene expression from one variant to the next. Taking all of these factors into account, however, the differences in the expression between $\alpha$-chain and $\beta$-chain variants seems valid.

One possible explanation for at least part of the variability is that $\alpha$-chain mutants are more sensitive to amino acid substitution. That possibility has not been excluded. Nevertheless, in a number of mutants the qualitative abnormali-

* Supported by U.S.P.H.S. Grant No. GM-15419.

† Visiting Professor, Departments of Pediatrics and Medicine, Center for Sickle Cell Disease, Howard University College of Medicine. 
FIGURE 1. Diagram of electrophoretic pattern at $\mathrm{pH} 8.6$ of $\mathrm{Hb} \mathrm{J} \alpha$ Buda $\alpha 61$ Lys $\rightarrow$ Asn and $\mathrm{Hb} \mathrm{G} \alpha$ Pest a 74 Asp $\rightarrow$ Asn. Each mutant comprises approximately $25 \%$ of the total hemoglobin.

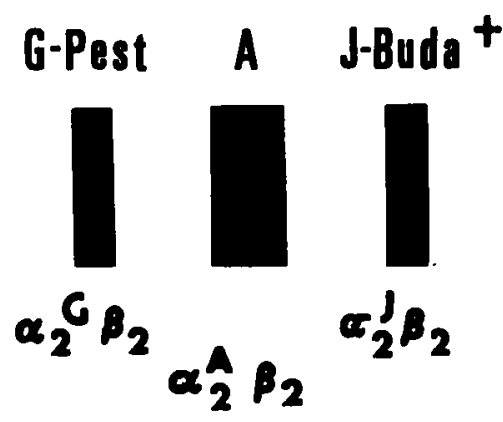

ties and genetic data allow inferences regarding multiple loci as the explanation.

\section{Hb J Buda and G Pest}

The first is a Hungarian Caucasian family in which three brothers possess, in addition to $\mathrm{Hb} \mathrm{A}$, two abnormal hemoglobins with variant $\alpha$-chains, (FIGURE 1) $\mathrm{Hb} \mathrm{J}$ Buda and Hb G Pest. ${ }^{13}, 14$ These are distinct and independent mutants, the former having an asparagine molecule substituted for lysine at residue 61 and the latter an asparagine for aspartic acid at position 74. These men transmitted one or the other gene to six of their offspring. These observations indicate that these persons have two $H b_{\alpha}$ loci, each locus having one mutant allele and one $\alpha^{A}$ allele from which the $\mathrm{Hb} A$ is derived (FIgURE 2). Each variant comprises approximately $20 \%$ of the total hemoglobin, suggesting that the two loci contribute equally to the $\alpha$-chain pool. In addition, one son of each of the brothers reportedly had only $\mathrm{Hb} \mathrm{A}$, suggesting that the two $H b_{\alpha}$ loci are not closely linked. Subsequent genotyping has cast doubt upon the paternity of these offspring, however, leaving the linkage of the two loci in doubt. ${ }^{13}, 14$ In addition, the amino acid composition of all of the tryptic peptides of the three types of $\alpha$ chains present in these three brothers are identical, indicating that there are no amino acid differences between the chains normally produced by the two loci.

\section{Hb J Tongariki}

A second seemingly contradictary family is from a Kilenge village in New Britain. In it numerous individuals are heterozygous for $\mathrm{Hb} \mathrm{J}$ Tongariki, $\alpha 115$ Ala $\rightarrow$ Asp, a rapidly migrating component comprising 45 to $50 \%$ of the total

FIGURE 2. Diagramatic representation of the relationship of the two loci in a heterozygote for $\mathrm{Hb} \mathrm{J} \alpha$ Buda and $\mathrm{Hb}$ $G \alpha$ Pest (left) and in a heterozygote for $\mathrm{Nb} \mathrm{J} \propto$ Tongariki (right).

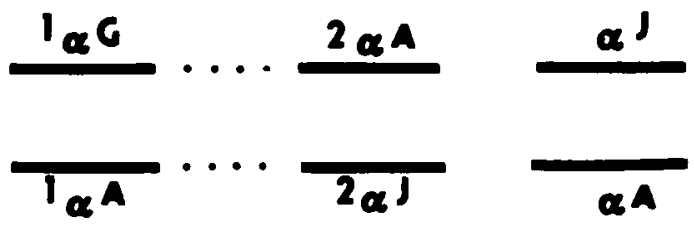


TABLE 1

The Proportion of Abnormal Hemoglobin in Heterozygotes for Structural Mutants *

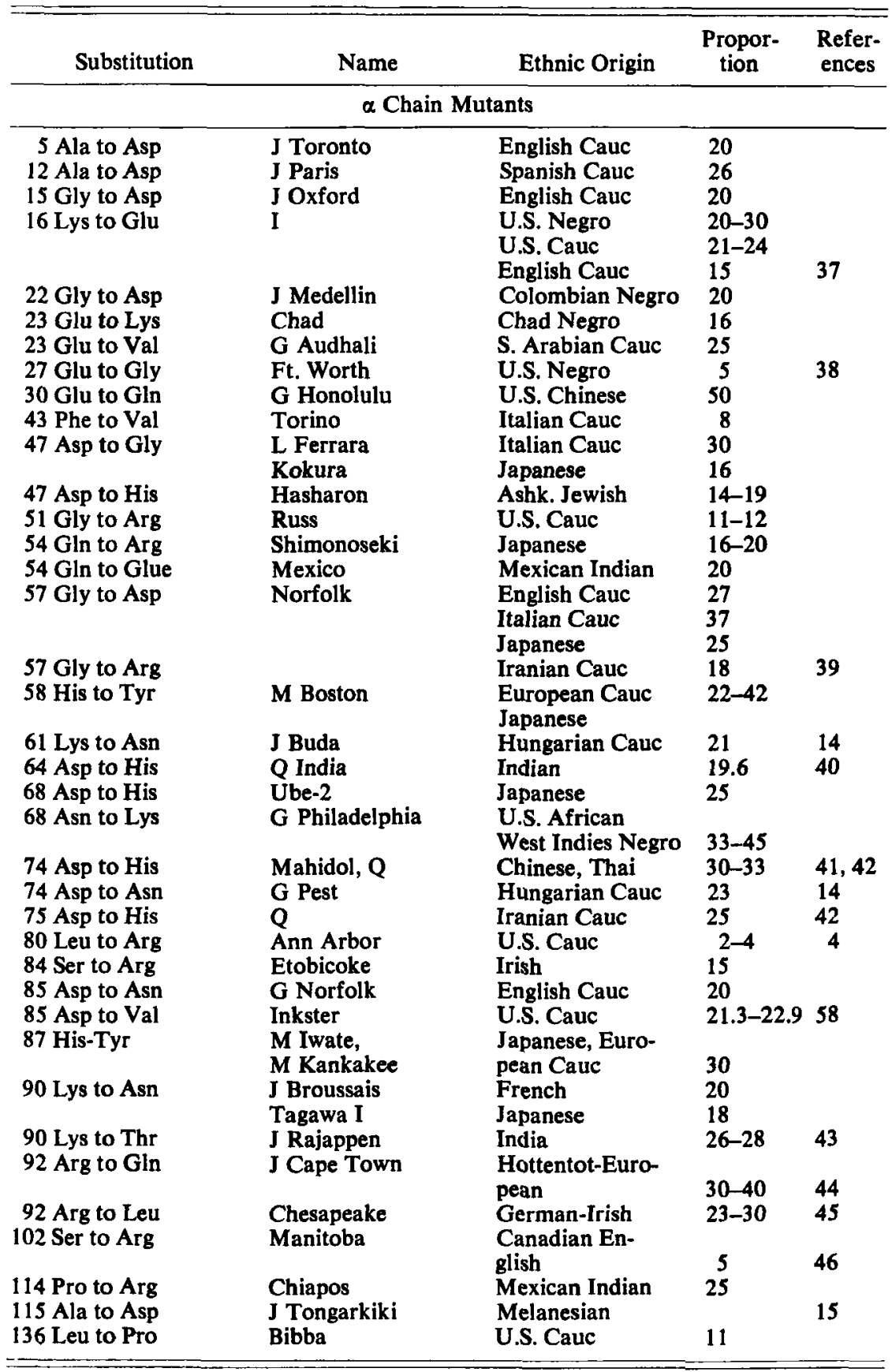


TABLE 1 (Continued)

\begin{tabular}{|c|c|c|c|c|}
\hline Substitution & Name & Ethnic Origin & $\begin{array}{l}\text { Propor- } \\
\text { tion }\end{array}$ & $\begin{array}{l}\text { Refer- } \\
\text { ences }\end{array}$ \\
\hline \multicolumn{5}{|c|}{$\beta$ Chain Mutants } \\
\hline 6 Glu to Val & $\mathbf{S}$ & $\begin{array}{l}\text { African, Middle } \\
\text { East, Indian Abo- } \\
\text { rigines, Greeks, } \\
\text { Sicilian }\end{array}$ & $25-45$ & \\
\hline $\begin{array}{l}6 \text { Glu to Lys } \\
6 \text { or } 7 \text { Glu deletion } \\
7 \text { Glu to Lys } \\
9 \text { Ser to Lys }\end{array}$ & $\begin{array}{l}\text { C } \\
\text { Leiden } \\
\text { Siriraj } \\
\text { Porto Alegre }\end{array}$ & $\begin{array}{l}\text { W. African } \\
\text { Dutch Cauc } \\
\text { Thai } \\
\text { Brazilian Portu- } \\
\text { guese }\end{array}$ & $\begin{array}{l}30-40 \\
30 \\
40 \\
20\end{array}$ & \\
\hline $\begin{array}{l}14 \text { Leu to Arg } \\
16 \text { Gly to Arg }\end{array}$ & $\begin{array}{l}\text { Sogn } \\
\text { D Bushman }\end{array}$ & $\begin{array}{l}\text { Norwegian } \\
\text { Kalahari Bush- } \\
\text { man }\end{array}$ & $\begin{array}{l}30-32 \\
37\end{array}$ & \\
\hline 16 Gly to Asp & J Baltimore & $\begin{array}{l}\text { U.S. Negro, En- } \\
\text { glish, Dutch Cauc }\end{array}$ & $40-53$ & \\
\hline $\begin{array}{l}20 \text { Val to Met } \\
22 \text { Glu to Ala } \\
22 \text { Glu to Lys } \\
22 \text { Glu to Gln } \\
23 \text { Val deletion } \\
24 \text { Gly to Arg } \\
25 \text { Gly to Arg }\end{array}$ & $\begin{array}{l}\text { Olympia } \\
\text { G Coushatta } \\
\text { E Saskatoon } \\
\text { D Iran } \\
\text { Freiburg } \\
\text { Riverdale-Bronx } \\
\text { G Taiwan-Ami }\end{array}$ & $\begin{array}{l}\text { U.S. Cauc } \\
\text { American Indians } \\
\text { Scottish Cauc } \\
\text { Iranian Cauc } \\
\text { German Cauc } \\
\text { German Jewish } \\
\text { Taiwan Abori- } \\
\text { gines }\end{array}$ & $\begin{array}{l}40 \\
50 \\
40 \\
40 \\
27-32 \\
30\end{array}$ & \\
\hline $\begin{array}{l}26 \text { Glu to Lys } \\
28 \text { Leu to Pro } \\
30 \text { Arg to Ser } \\
35 \text { Tyr to Phe } \\
37 \text { Try to Ser } \\
42 \text { Phe to Leu } \\
42 \text { Phe to Ser } \\
43 \text { Glu to Ala } \\
46 \text { Gly to Glu } \\
52 \text { Asp to Asn } \\
56 \text { Gly to Asp } \\
58 \text { Pro to Arg } \\
58 \text { Pro to Arg } \\
61 \text { Lys to Asn } \\
61 \text { Lys to Glu } \\
63 \text { His to Arg } \\
63 \text { His to Tyr }\end{array}$ & $\begin{array}{l}\text { E } \\
\text { Genova } \\
\text { Tacoma } \\
\text { Philly } \\
\text { Hirose } \\
\text { Bucuresti } \\
\text { Hammersmith } \\
\text { G Galveston } \\
\text { K Ibadan } \\
\text { Osu-Christiansborg } \\
\text { J Bangkok } \\
\text { Dhofar } \\
\text { Jukuhashi } \\
\text { Hikari } \\
\text { N Seattle } \\
\text { Zurich } \\
\text { M Saskatoon }\end{array}$ & $\begin{array}{l}\text { S.E. Asian } \\
\text { Italian Cauc } \\
\text { U.S. Cauc } \\
\text { Italian Cauc } \\
\text { Japanese } \\
\text { Roumanian Cauc } \\
\text { English Cauc } \\
\text { U.S. Negro } \\
\text { Yoruka (Nigeria) } \\
\text { Ghana Negro } \\
\text { Thai } \\
\text { So. Arabian } \\
\text { Japanese } \\
\text { Japanese } \\
\text { U.S. Negro } \\
\text { Swiss Cauc } \\
\text { European Cauc, } \\
\text { Japanese }\end{array}$ & $\begin{array}{l}22-40 \\
25 \\
43 \\
30-35 \\
30 \\
45 \\
30 \\
40-50 \\
50 \\
36 \\
50-60 \\
15 \\
40-56 \\
54 \\
50 \\
20-36 \\
30-40\end{array}$ & \\
\hline $\begin{array}{l}74 \text { Gly to Asp } \\
74-75 \text { Gly-Leu deletion } \\
76 \text { Ala to Glu } \\
77 \text { His-asp } \\
79 \text { Asp to Asn }\end{array}$ & $\begin{array}{l}\text { Sheperds Bush } \\
\text { St. Antoine } \\
\text { Seattle } \\
\text { J Iran } \\
\text { G Accra }\end{array}$ & $\begin{array}{l}\text { Japanese } \\
\text { S. Afr. English } \\
\text { French } \\
\text { U.S. Cauc } \\
\text { Iranian Cauc } \\
\text { Ghangian, Jamai- } \\
\text { can Negro }\end{array}$ & $\begin{array}{l}30-40 \\
24 \\
25 \\
40 \\
50 \\
50\end{array}$ & \\
\hline $\begin{array}{l}87 \text { Thr deletion } \\
90 \text { Glu to Lys } \\
91 \text { Leu to Pro }\end{array}$ & $\begin{array}{l}\text { Tours } \\
\text { Agenagi } \\
\text { Sabine }\end{array}$ & $\begin{array}{l}\text { French } \\
\text { Japanese } \\
\text { English-Scottish- } \\
\text { German }\end{array}$ & $\begin{array}{l}25 \\
40-44 \\
8\end{array}$ & \\
\hline $92 \mathrm{His}$ to Tyr & M Hyde Park & U.S. Negro & 40 & \\
\hline
\end{tabular}


TABLe 1 (Continued)

\begin{tabular}{|c|c|c|c|c|}
\hline Substitution & Name & Ethnic Origin & $\begin{array}{l}\text { Propor- } \\
\text { tion }\end{array}$ & $\begin{array}{l}\text { Refer- } \\
\text { ences }\end{array}$ \\
\hline $\begin{array}{l}92 \text { His to Tyr } \\
92 \text { His to Glu } \\
15 \text { Lys to Glu } \\
97 \text { His to Gln } \\
98 \text { Val to Met }\end{array}$ & $\begin{array}{l}\text { M Aikita } \\
\text { Istanbul } \\
\text { N-Baltimore } \\
\text { Malmö } \\
\text { Köln }\end{array}$ & $\begin{array}{l}\text { Japanese } \\
\text { Turkish Cauc } \\
\text { U.S. Negro } \\
\text { U.S. Swedish } \\
\text { English-Scottish- } \\
\text { German }\end{array}$ & $\begin{array}{l}30 \\
12-15 \\
50 \\
48 \\
\\
10-15\end{array}$ & \\
\hline $\begin{array}{l}99 \text { Asp to His } \\
99 \text { Asp to Tyr } \\
102 \text { Asn to Thr } \\
106 \text { Leu to Pro } \\
120 \text { Lys to Glue } \\
121 \text { Glu to Gln }\end{array}$ & $\begin{array}{l}\text { Yakima } \\
\text { Ypsilanti } \\
\text { Kansas } \\
\text { Casper } \\
\text { Hijiyama } \\
\text { D Punjah }\end{array}$ & $\begin{array}{l}\text { Swedish } \\
\text { U.S. Negro } \\
\text { U.S. Cauc } \\
\text { U.S. Cauc } \\
\text { Japanese } \\
\text { Indian, Iranian }\end{array}$ & $\begin{array}{l}37-38 \\
37 \\
51 \\
30-40 \\
58\end{array}$ & \\
\hline 121 Glu to Lys & O Arab & $\begin{array}{l}\text { European, Thai } \\
\text { Sudanese, Egyp- } \\
\text { tian, Bulgarian, } \\
\text { U.S. Negro }\end{array}$ & $30-40$ & \\
\hline $\begin{array}{l}126 \text { Val to Glu } \\
136 \text { Gly to Asp } \\
143 \text { His to Asp } \\
145 \text { Tyr to His } \\
91-98 \text { Deletions } \\
\text { 145-156 Addition }\end{array}$ & $\begin{array}{l}\text { Hofu } \\
\text { Hope } \\
\text { Hiroshima } \\
\text { Ranier } \\
\text { Gun Hill } \\
\text { Tak }\end{array}$ & $\begin{array}{l}\text { Japanese } \\
\text { U.S. Negro } \\
\text { Japanese } \\
\text { U.S. Cauc } \\
\text { German-English } \\
\text { Thai }\end{array}$ & $\begin{array}{l}50 \\
40-45 \\
51 \\
30 \\
50 \\
40\end{array}$ & \\
\hline
\end{tabular}

* Modified from De Jong. See this source for additional references.

hemoglobin. ${ }^{15}$ In that family there were two individuals who were apparent homozygotes, having no $\mathrm{Hb} \mathrm{A}$ or $\mathrm{Hb} \mathrm{A}_{2}$, suggesting that these individuals possess only one $H b_{\alpha}$ locus (Figure 2). Unfortunately, both of the parents of these individuals were not available for study. An obvious alternate hypothesis is that these individuals also carry an $\alpha$-thalassemia gene responsible for the complete suppression of synthesis of $\alpha^{\Lambda}$ chains. This in itself would be remarkable, if, in fact, there are two $H b_{\alpha}$ loci present, both of which were influenced by a pair of $\alpha$-thalassemia alleles. Nevertheless, there were no hematologic manifestations suggestive of thalassemia, and the high frequency of heterozygotes among individuals marrying into this family increased the odds that these two individuals were indeed homozygotes. Subsequently three additional homozygotes were observed among 717 inhabitants of KarKar, an island off the northern coast of New Guinea. ${ }^{16}$ Again the parents of the apparent homozygotes were not studied. In the meantime, one of us (DLR) has restudied the New Britain family with Dr. Jan Saave, and this study should put the question to rest. ${ }^{17}$ In that family one of the homozygotes was married to a heterozygote but blood had not been obtained from their only child. ${ }^{15}$ Now we have obtained blood from their two children and both are homozygotes. In addition, a trait by trait mating also produced a homozygote. Thus, at least some Melanesians have only one $H b_{\alpha}$ locus.

Structural data for Hb Hopkins-2 are purported 18 to show a mixture of two abnormal $\alpha$ chains in both of which aspartic acid is substituted for the normally occurring histidine at residue 112. But one chain also contains two 
additional substitutions at positions 114 and 118 . The authors believe that there are normally two $H b_{\alpha}$ loci encoding chains that differ at the latter two residues. They propose that the substitutions at position 112 arose as a point mutation in one locus and then became transmitted to the other by unequal crossing over. These conclusions are based upon leucine aminopeptidase digestions of peptides isolated from tryptic digests by Dowex column chromtography followed by purification by paper electrophoresis. The latter technique cannot be relied upon to purify the peptides sufficiently to allow the interpretations rendered. Furthermore, Brimhall and colleagues ${ }^{14}$ examined the amino acid composition of every tryptic peptide of the $\alpha$ chains of the $\mathrm{Hb} \mathrm{A}$, the $\mathrm{Hb} \mathrm{J}$ Buda, and the $\mathrm{Hb}$ G Pest of one of their doubly heterozygous individuals and found no evidence for other differences in amino acid composition of the $\alpha$ chains of the two loci. Therefore, these findings on Hb Hopkins- 2 must be held in abeyance until confirmation by more reliable methods.

\section{A Hypothesis For Variable Numbers of a Loci}

Additional evidence bearing upon the number of $H b_{\alpha}$ loci has come to our attention through the family of a child who is heterozygous for $\boldsymbol{H} \boldsymbol{b}_{\alpha}{ }_{\alpha}$-Phlladelphla $H b_{\beta}{ }^{\mathrm{g}}$ and $H b_{\beta}{ }^{\mathrm{C}}{ }^{19}$ In this family seven individuals were heterozygous for both $H b_{\alpha} \mathrm{G}$ and $H b_{\beta} \mathrm{s}$ and five were heterozygous for the $H b_{\alpha}{ }^{\mathrm{G}}$ allele only. Among the latter, two had approximately $40 \%$ of $\mathrm{Hb} \mathrm{G}$ whereas three had values of $28.5,30.2$, and $30.9 \%$ as measured by elution ${ }^{20}$ from cellulose acetate electrophoresis strips (TABLE 2). This method is quite reproducible and more accurate than densitometry. ${ }^{21}$ We perceive these values as beyond the range of variation encountered within most families with $\mathrm{Hb} \mathrm{S}$ or $\mathrm{Hb} \mathrm{C}$ trait, suggesting that the proportion of $\mathrm{Hb} \mathrm{G}$ is bimodally distributed.

Having made this observation, we then scrutinized other data on $\mathrm{Hb} \mathrm{G}$ in our possession. Rising and colleagues ${ }^{22}$ have described a family in which both $H b_{\beta}{ }^{\mathrm{g}}$ and $H b_{\alpha}^{\text {G-Philadelphia }}$ are segregating and in which two individuals are heterozygous only for $H b_{\alpha}{ }^{G}$. We also quantified the proportion of $\mathrm{Hb} \mathrm{G}$ in those persons' blood employing the technique used above (they employed densitometric analysis of cellulose acetate electrophoretic strips in their report). We obtained 27.0 and $29.0 \% \mathrm{Hb} \mathrm{G}$ on these two specimens (TABLE 2). We have also examined four specimens obtained from presumably unrelated persons in a survey of 25,000 Negroes enrolled in the Job Corps of the United States Government, ${ }^{23}$ for which we were a reference laboratory. These four values were $39.2 ; 40.0 ; 28.9$; and $27.8 \%$ of $\mathrm{Hb}$ G (TABLE 2). Thus, among eleven specimens, four clustered around $40 \% \mathrm{Hb} \mathrm{G}$ and seven around $30 \%$. Since these data were examined retrospectively, a proper analysis of variance that took into account replicability of the technique could not be employed.

We propose that the apparent bimodality in the proportion of $\mathrm{Hb} \mathrm{G}$ is due to variability in the number of $H b_{\alpha}$ loci among Negroes, such that individuals with $40 \%$ of $\mathrm{Hb} \mathrm{G}$ have only one $H b_{\alpha}$ locus, whereas those with $30 \%$ of $\mathrm{Hb} \mathrm{G}$ possess an additional $H b_{\alpha}$ gene derived from a second locus (FIgURE 3 ). Values clustering around 15 to $20 \%$ of an abnormal $\alpha$-chain variant ( $\mathrm{Hb} \mathbf{X}$, Figure 3), thus far not observed with $\mathrm{Hb} \mathrm{G} \alpha$ Philadelphia, would suggest that these persons possess two $H b_{\alpha}$ loci; that is, one mutant and three normal genes. We shall assume in the ensuing discussion that the two loci are closely linked, although this need not be so. The occurrence of low proportions of $\mathrm{Hb} \mathrm{G}$ 
TABLe 2

Hematologic Values and Proportion of Electrophoretic Components in HB Ga Philadelphia

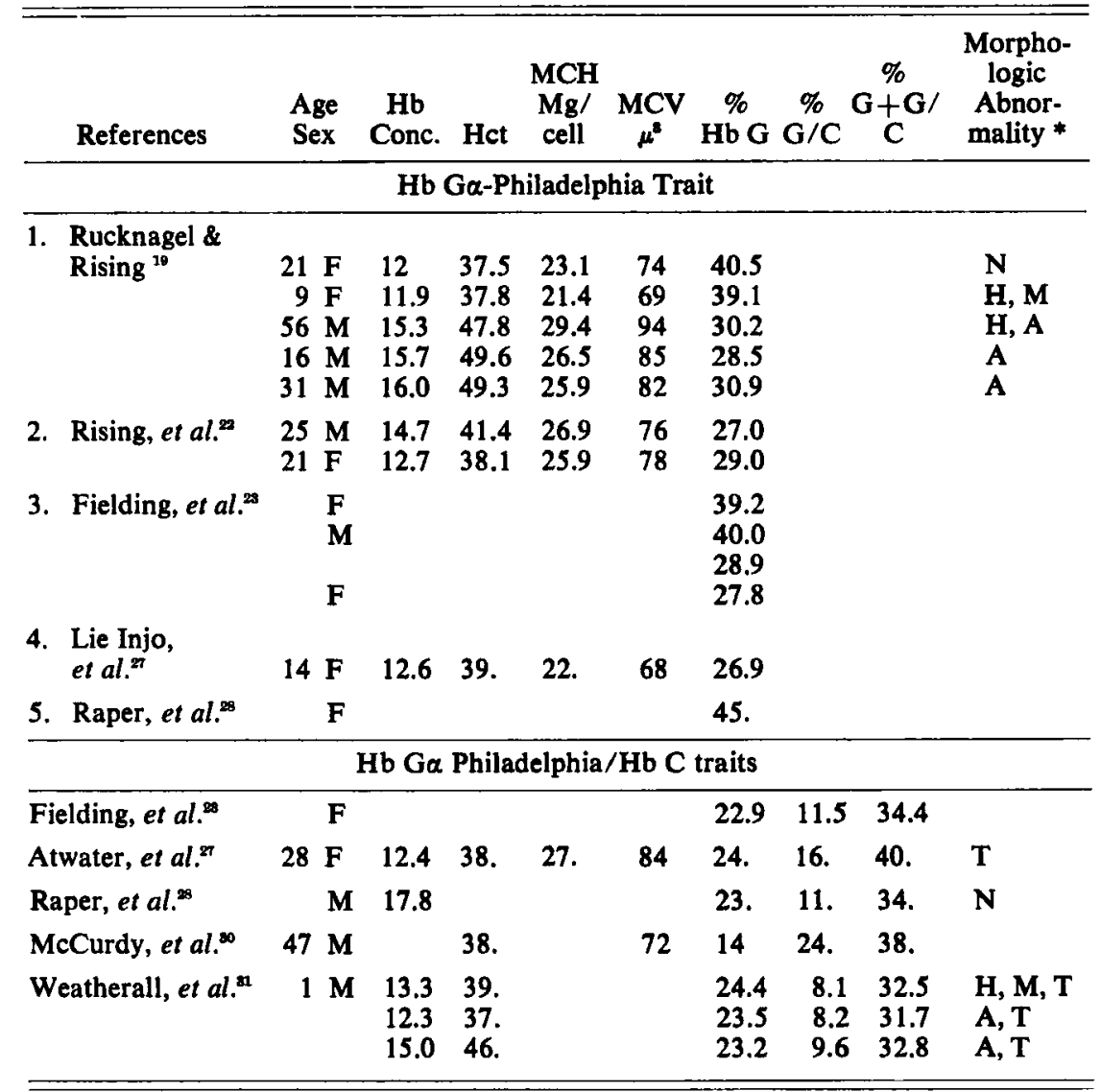

* $N=$ normal; $H=$ hypochromic; $M=$ microcytic; $A=$ anisocytosis; $T=$ target cells.

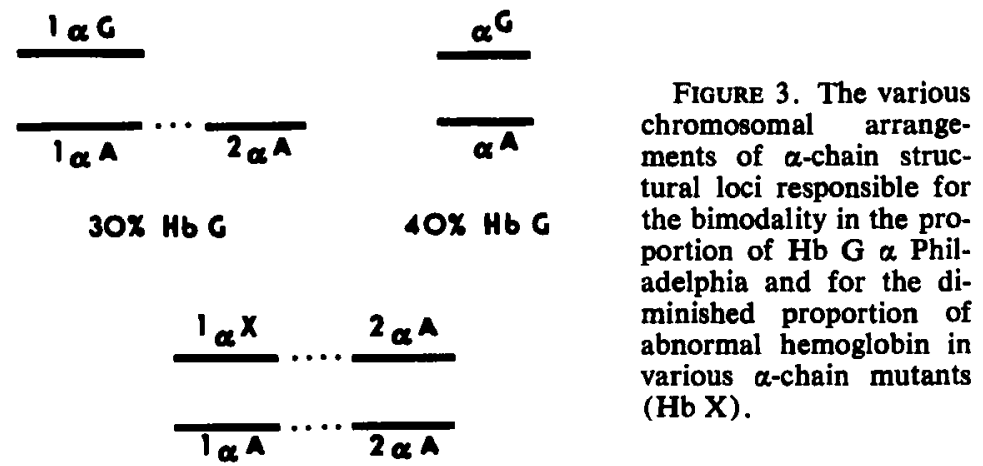

$20 \% \mathrm{HbX}$ 
Philadelphia would suggest that crossing over had occurred between a chromosome bearing a single $H b_{\alpha}$ gene and one bearing two $H b_{\alpha}$ loci.

Other possible explanations cannot be completely excluded, given the paucity of data. The most obvious one is that the persons with the greater amount of $\mathrm{Hb} \mathrm{G}$ are also heterozygous for an $\alpha$-thalassemia gene. French and Lehmann, ${ }^{24}$ concerned that the high proportions imputed to $\mathrm{Hb} \mathrm{G} \alpha$ Philadelphia and $\mathrm{Hb} \mathrm{Ga}$ Honolulu are incompatible with the two loci hypothesis, further proposed that this is due to linkage in the coupling phase of the $\mathrm{Hb} \mathrm{G}$ and $\alpha$-thalassemia genes. To support this contention they described a mother and three children with $\mathrm{Hb} \mathrm{G}$ trait who had red cells resistant to hypotonic saline. Martinez and colleagues ${ }^{25}$ observed a slightly decreased osmotic fragility also in an individual heterozygous for this same mutant. The two siblings with $40 \% \mathrm{Hb} \mathrm{G}$ in the "index family" described above ${ }^{19}$ were microcytic, suggesting that either $\alpha$ thalassemia or iron deficiency is also present; inasmuch as they were young females and from poor families they are more likely to be iron deficient. Furthermore, other isolated individuals in that family having other genotypes had inconsistent hematologic abnormalities, suggesting sporadic nutritional deficiencies. We think these abnormalities are not indicative of a closely linked $\alpha$-thalassemia gene because heterozygotes for $\mathrm{Hb}$ I and $\alpha$-thalassemia ${ }^{25}$ or $\beta$-chain structural variants and $\beta$ thalassemia have $70 \%$ or more of the abnormal hemoglobin. In addition, we have not observed consistent hematologic evidence for such a phenomenon accompanying the $H b_{\alpha}{ }^{G}$ allele among the twelve relatives of the "index family" who had the $H b_{\alpha}{ }^{G}$ gene in combination with heterozygosity for $\mathrm{Hb}_{\beta}{ }^{\mathrm{s}}$; at most slight anisocytosis was a frequent accompaniment of the gene. Finally, osmotic fragility changes noted by French and Lehmann ${ }^{24}$ could also be effects of the $\mathrm{Hb} \mathrm{G}$ per se, rather than thalassemia, analogous to the target cells regularly observed in heterozygotes for $H b_{\beta}{ }^{\mathrm{C}}$ or $H b_{\beta}{ }^{\mathrm{E}}$.

Further data bearing upon this hypothesis have been garnered from the literature (TABLE 2). Since different amino acid substitutions may affect synthesis differently (as demonstrated by the variability among $H b_{\beta}$ mutants), only the data for $\mathrm{Hb} \mathrm{G}$ Philadelphia, the most common of the $H b_{\alpha}$ mutants, are presented. Older data, probably from $\mathrm{Hb} \mathrm{G}$ Philadelphia but in which the identity of the mutant had not been established by peptide mapping have been excluded. The data should also be scrutinized with the realization that different methods of quantification are employed in the various reports. Lie-Injo and colleagues ${ }^{27}$ described one heterozygote with $26.9 \% \mathrm{Hb}$ G, whereas Raper and colleagues ${ }^{28}$ described another with $45 \%$. Six individuals who are heterozygous for $H b_{\alpha}{ }^{\text {G-Phlladelphia }}$ and $H b_{\beta}{ }^{\mathrm{C}}$ have been described. ${ }^{28-31}$ Among the four components visible upon electrophoresis, the sum of the $\mathrm{Hb} \mathrm{G}$ and the $\mathrm{G} / \mathrm{C}$ hybrid reflects the amount of $\alpha$-chain content. The values obtained for these two components vary between 31.7 and $40 \%$ (TABLE 2). One such person in the Job Corps study possessed $34.5 \%$ of the two components. These data should not be pooled with those for the simple $\mathrm{Hb}$ G trait, but only the within-group variation considered for evidence of bimodality.

Numerous individuals heterozygous for $H b_{\alpha}{ }_{\alpha}^{\text {G-Phlladelphia }}$ and $H b_{\beta}{ }^{\mathrm{C}}$ have been reported. In this genotype the $\mathrm{Hb} \mathrm{S}$ and $\mathrm{Hb} \mathrm{G}$ molecules migrate identically or nearly so. The proportion of $\mathrm{Hb} \mathrm{G/S}$ hybrid is not informative since in the model described above-and assuming $\beta^{s}$ chains comprise $35 \%$ of the total $\beta$-chain content-the proportion of $\mathrm{G} / \mathrm{S}$ expected in the two- and three- 
gene models are 14.0 and $10.5 \%$, respectively, too small a difference to provide an adequate test of the model.

\section{Population Implications}

$\mathrm{Hb} \mathrm{G} \propto$ Philadelphia is widely distributed in American Negroes at a trait frequency ${ }^{23}$ of approximately one in 5,000, indicating that the gene is of African origin. From TABLE 1 it is apparent from the fact that none of the $H b_{\alpha}$ mutants in Caucasians possess over $30 \%$ of the variant molecule that most Caucasians have two $\mathrm{Hb}_{\alpha}$ loci. Assuming the above hypothesis regarding heterogeneity of $H b_{\alpha}$ loci in American Negroes to be correct, the proportion of unrelated persons having high and low proportions of $\mathrm{Hb} \mathrm{G}$ provide an estimate of the frequency of the second locus in this race. Family data present a more complicated situation in that, when siblings with the $\mathrm{Hb} \mathrm{G}$ trait fall in the same mode, one cannot be certain of the genotype of the non-Hb $\mathrm{G}$ parent until a large number of offspring with the trait have proven to have uniform proportions of $\mathrm{Hb} \mathrm{G}$, whereas when siblings fall in the different classes the parent not having $H b_{\alpha}{ }^{G}$ is thereby shown to have three $H b_{\alpha}{ }^{A}$ genes. In the collection of data described in this report we have identified eight chromosomes homologous to $\mathrm{H} b_{\alpha}{ }^{G}$ to be counted. In a single sibship of the "index family" ${ }^{10}$ two sisters have $40 \%$ and a brother $30 \%$ of $\mathrm{Hb} \mathrm{G}$, so we have counted the chromosomes of the non-Hb $\mathrm{G}$ parent as one single and one double locus chromosome. In another sibship of this family a single heterozygote had $30 \%$ of $\mathrm{Hb} \mathrm{G}$ so we count the chromosome not containing $\mathrm{Hb} \mathrm{G}$ of that person as a two-locus chromosome. In the family of Rising and colleagues ${ }^{22}$ the two persons with approximately $30 \% \mathrm{Hb} \mathrm{G}$ trait are siblings so we had discarded one of them in order to not count the same parental chromosome twice. The four Job Corpsmen with $H b_{\alpha}{ }^{\mathrm{G}}$ trait are presumably unrelated, so their non$\mathrm{Hb} \mathrm{G}$ chromosomes are counted. Thus, among eight chromosomes, five presumably bear two $\mathrm{Hb}_{\alpha}$ loci (yielding $30 \% \mathrm{Hb} \mathrm{G}$ ) and three were chromosomes having only one $H b_{\alpha}$ locus (yielding $40 \% \mathrm{Hb} \mathrm{G}$ ). Although this is a very small body of data on which to base an estimate, nevertheless, assuming that $25 \%$ of the genes in the American Negro gene pool are of Caucasian origin, ${ }^{32}$ we can estimate that the frequency of the chromosome bearing only one $H b_{\alpha}$ locus among African Negroes is $3 / 8 \times 4 / 3=0.5$. The finding of Brimhall and colleagues ${ }^{14}$ that the $\alpha$-chains produced by the two $H b_{\alpha}$ loci have identical amino acid compositions suggests that the duplication of the two loci in Caucasians, most likely by the process of unequal crossing over, was too recent an event for mutational differences to have arisen and become fixed.

The nature of the selective pressure responsible for the difference in the frequency of the two chromosomes in the two races is unclear. If the racial frequencies were reversed and Negroes had a higher frequency of the second locus, one would be tempted to assume that the same selection pressures resulting in the high frequencies of $H b_{\beta}{ }^{8}$ and $H b_{\beta}$ c are responsible for the two $H b_{\alpha}$ loci. The prevalence of multiple $H b_{\alpha}$ loci among a large number of different species of animals compels one to look for a more general mechanism, however. Boyer (this volume) has suggested a population genetic mechanism. It seems to us that a physiologic mechanism of selection pressure may be related to the switching from embryonic to fetal to adult hemoglobin that is prevalent also among many species. Presumably differing needs of the fetus and adult favor differing non- $\alpha$ loci. Thus differing $H b_{\alpha}$ loci may also be required. In most 
animals the primary structure of the various $\alpha$ chains differ so that the argument can be couched in qualitative terms. In man, the primary structure of the two $\alpha$ chains appears identical, ${ }^{14}$ so it is necessary to argue in more quantitative terms; namely, that either the adult or fetus finds it advantageous to possess more than one copy of the $H b_{\alpha}$ locus.

\section{Duplication of $\beta$-Chain Loci}

At first glance, the fact that homozygotes for the gene for sickle cell anemia, $\mathrm{Hb} \mathrm{C}$, or $\mathrm{Hb} \mathrm{E}$ have no $\mathrm{Hb} \mathrm{A}$ indicates the existence of only one structural locus for $\beta$ polypeptide chains. In 1963 Nance ${ }^{33}$ proposed that some persons may have a chromosomes in which the $H b_{\beta}{ }^{\mathbb{S}}$ and $H b_{\beta}{ }^{\wedge}$ genes are closely linked. This proposal was made in part to explain the apparent bimodality in the proportion of Hb S among heterozygotes. The most likely explanation for that bimodality is the coexistence of a gene for $a$ thalassemia, which is present in approximately $2 \%$ of the American Negro population. ${ }^{34}$ Nance further proposed that such a tandem duplication would result in a deficiency of apparent homozygotes among trait by trait matings if unbiased population data were scrutinized. Family data ascertained through the presence of clinically affected homozygotes would be expected to be biased toward the single $H b_{\beta}$ chromosome. It is unlikely that the existence of a tandem duplication can be proven by such family data, however, since even family data ascertained through symptomatic homozygotes show a deficiency of this genotype, perhaps due to loss of homozygotes in utero. ${ }^{35}$ The data at the present time, therefore strongly favor only a single $H b_{\beta}$ locus.

Duplication of the $H b_{\alpha}$ and $H b_{\gamma}$ loci in man is supported by a growing body of data. This mechanism must be seriously contemplated when formulating models for genetic variability in man.

\section{Acknowledgments}

The authors gratefully acknowledge the technical assistance of Ms. Floretta Reynolds and Ms. Dorothy Sweet.

\section{References}

1. Schroeder, W. A., T. H. J. Huisman, J. R. Shelton, J. B. Shelton, E. F. Kleihauer, A. M. Dozy \& B. Robberson. 1968. Evidence for multiple structural genes for the gamma chain of human fetal hemoglobin. Proc. Nat. Acad. Sci. U.S. 60: 537-544.

2. Huisman, T. H. J., W. A. Schroeder, W. H. Bannister, J. L. Grech. 1972. Evidence for four nonallelic structural genes for the $\gamma$-chain of human fetal hemoglobin. Biochem. Genet. 7: 131-139.

3. LehmanN, H. \& R. W. Carrell. 1968. Differences between $\alpha$ - and $\beta$-chain mutants of human haemoglobin and between $\alpha$ - and $\beta$-thalassaemia. Possible duplication of the $\alpha$-chain gene. Brit. Med. J. 4: 748-750.

4. Adams, J. G., III, W. P. Winter, D. L. Rucknagel \& H. H. SPencer. 1972. Biosynthesis of hemoglobin Ann Arbor: Evidence for catabolic and feedback regulation. Science 176: $1427-1429$. 
5. Beretta, A., V. Prato, E. Gallo \& H. Lehmann. 1968. Haemoglobin Torino $\alpha-43$ (CD1) phenylalanine to valine. Nature 217: 1016 .

6. KLeihAUER, E. F., et al. 1968. Hemoglobin Bibba or $\alpha_{2}^{136 P r o} \beta_{2}$, an unstable $\alpha$-chain abnormal hemoglobin. Biochem. Biophys. Acta 154: 220-222.

7. Raper, A. B., D. B. Gammack, E. R. Huehns \& E. M. Shooter. 1960. Four haemoglobins in one individual. A study of the genetic interaction of Hb-G and $\mathrm{Hb}-\mathrm{C}$. Med. J. 2: 1257-1261.

8. Swenson, R. T., R. J. Hill, H. Lehmann \& R. T. S. Jim. 1962. A chemical abnormality in haemoglobin $G$ from Chinese individuals. J. Biol. Chem. 237: 1517.

9. Sansone, G., R. W. Carrell \& H. Lehmann. 1967. Haemoglobin Genova: beta 28 (B10) leucine replaced by proline. Nature 214: 877-879.

10. Muller, C. J. \& S. Kingma. 1961. Haemoglobin Zürich $\propto \stackrel{A}{2}_{\beta 2}^{63 A r g}$. Biochim. Biophys. Acta 50: 595 .

11. Schneider, R. G., S. Ueda, J. B. Alperin, B. Brimhall \& R. T. Jones. 1969. Hemoglobin Sabine beta 91 (F7) Leu $\rightarrow$ Pro. An unstable variant causing severe anemia with inclusion bodies. N. Engl. J. Med. 280: 739-745.

12. Carrell, R. W., H. Lehmann \& H. E. Hutchson. 1966. Haemoglobin Köln ( $\beta$-98 valine $\rightarrow$ methionine): An unstable protein causing inclusion body anaemia. Nature 210: 915-916.

13. Hollan, S. R., J. G. Szelenyi, B. Brimhall, M. Duerst, R. T. Jones, R. D. KOLER \& Z. STOCKLEN. 1972. Multiple alpha chain loci for human haemoglobins: Hb J-Buda and Hb G-Pest. Nature 235: 47-50.

14. Brmmhall, B., M. Duerst, S. R. Hollan, P. Stenzel, J. Szelenyi \& R. T. JoNEs. 1974. Structural characterizations of hemoglobins J-Buda [a 51(E10) Lys $\rightarrow$ Asn] and G-Pest [a 74(EF 3)Asp $\rightarrow$ Asn]. Biochim. Biophys. Acta In Press.

15. Abramson, R. K., D. L. Rucknagel, D. C. Shreffler \& J. J. SaAve. 1970. Homozygous $\mathrm{Hb}$ J Tongariki: Evidence for only one alpha chain structural locus in Melanesians. Science 169: 194-196.

16. Beaven, G. H., R. W. Hornabrook, R. H. Fox \& E. R. Huehns. 1973. Occurrence of heterozygotes and homozygotes for the $\alpha$-chain haemoglobin variant Hb $J$ (Tongariki) in New Guinea. Nature 235: 46-47.

17. Rucknagel, D. L. \& J. Sanve. Unpublished.

18. Ostertag, W., G. von Ehrenstein \& S. Charache. 1972. Duplicated $\alpha$-chain genes in Hopkins-2 Haemoglobin of man and evidence for unequal crossing over between them. Nature New Biol. 237: 90-94.

19. Rucknagel, D. L. \& J. A. Risino. 1974. A heterozygote for $H b^{\mathrm{s}}, H b^{\mathrm{c}}$, and

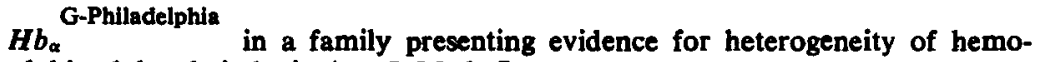
globin alpha chain loci. Am. J. Med. In press.

20. Glynn, K. P., J. A. Penner, J. R. Smith \& D. L. Rucknagel. 1968. Familial erythrocytosis: A description of three families, one with Hemoglobin Ypsilanti. Ann. Int. Med. 69: 769-776.

21. Schmidt, R. M., D. L. Rucknagel \& T. F. Necheles. 1973. Comparison of methodologies for thalassemia screening by $\mathrm{Hb} \mathrm{A}_{\mathrm{s}}$ quantitation. Abstracts, Sixteenth Annual Meeting. Am. Soc. Hematol. Chicago, Ill.

22. Rising, J. A., R. L. SAUTter \& S. J. SPICER. 1974. Hemoglobin G-Philadelphia/ S: A family study of an inherited hybrid hemoglobin. Am. J. Clin. Pathol. 61: 92-102.

23. Fieldino, J., P. Batalden, P. Tolbekt, R. Bennett \& S. H. Nelson. 1974. A coordinated sickle cell program for economically disadvantaged adolescents. Amer. J. Publ. Health. 64: 427-432.

24. French, E. A. \& H. Lehmann. 1971. Is Haemoglobin $\mathrm{G} \alpha$ Philadelphia linked to $\alpha$-thalassaemia? Acta Haematol. 46: 149-156. 
25. Martinez, G., H. Vidal \& B. Colombo. 1973. A further observation on the possible association between Haemoglobin $\mathrm{G} \alpha$-Philadelphia and $\alpha$-thalassaemia. Human Hered. 23: 157-163.

26. Atwater, J., I. R. Schwartz, A. J. Erslev, T. L. Montgomery \& L. M. Tocantins. 1960. Sickling of erythrocytes in a patient with thalassemiahemoglobin-I disease. N. Engl. J. Med. 263: 1215-1223.

27. Lie-Injo L. E., A. C. Wang \& R. C. BurnetT. 1968. Another family showing the interaction of the genes for $\mathrm{Hb} \mathrm{G}$ and $\mathrm{Hb} S$. Acta haematol. 40: 286-298.

28. Raper, A. B., D. B. Gammack, E. R. Huehns \& E. M. Shooter. 1960. Four Haemoglobins in One Individual. A study of the Genetic Interaction of $\mathrm{Hb}-\mathrm{G}$ and Hb-C. Brit. Med. J. 2: 1257-1261.

29. Atwater, J., I. R. Schwartz \& L. M. Tocantins. 1960. A variety of human hemoglobin with 4 distinct electrophoretic components. Blood 15: 901-908.

30. McCurdy, P. R., H. Pearson \& P. S. Gerald. 1961. A new hemoglobinopathy of unusual genetic significance. J. Lab. Clin. Med. 58: 86-94.

31. Weatherall, D. J., A. T. Sigler \& C. BAglioni. 1962. Four hemoglobins in each of three brothers. Genetic and biochemical significance. Bull. Johns Hopkins Hosp. 111: 143-156.

32. ReEd, T. E. 1969. Caucasian genes in American Negroes. Science 165: 762768.

33. NANCE, W. E. 1963. Genetic control of hemoglobin synthesis. Science 141: 123-130.

34. Weatherall, D. J. 1963. Abnormal haemoglobins in the neonatal period and their relationship to thalassemia. Brit. J. Haematol. 9: 265-277.

35. Rucknagel, D. L. 1973. Genetic basis of sickle cell disease. In Sickle Cell Disease Diagnosis, Management, Education, and Research. N. Abramson, J. F. Bertles, D. L. Wethers, Eds. C. V. Mosby, St. Louis, Mo.

36. DE JoNG, W. W. W. 1969. Structural Characterization of Some Mutants of Human Haemoglobin; Including Two New Variants. Ph. D. Thesis. Drukkerij Bronder-Offset. Rotterdam, Netherlands.

37. Labossiere, A. \& F. Vella. 1971. Hemoglobin I In a White Family in Saskatoon. Clin. Biochem. 4: 104-113.

38. SCHNEIDER, R. G., et al. 1971. Hb Ft. Worth: a $27 \mathrm{Glu} \rightarrow \mathrm{Gly}$ (B8). A variant present in unusually low concentration. Biochim. Biophys. Acta 243: 164-169.

39. Rahbar, S., J. L. Kinderlerer \& H. LehmanN. 1969. Haemoglobin L Persian Gulf; $\alpha 57$ (E6) Glycine $\rightarrow$ Argentine. Acta haematol. 42: 169-175.

40. Sukumaran, P. K., S. M. Merchant, M. P. Desai, B. G. Wiltshire \& H. LehMANN. 1972. Haemoglobin Q India ( $\alpha$ 64(E13) Aspartic Acid $\rightarrow$ Histidine) Associated with $a$-Thalassaemia Observed in Three Sindhi Families. J. Med. Genet. 9: 436-442.

41. Pootrakul, S. \& G. H. Dixon. 1970. Hemoglobin Mahidol: A new hemoglobin $\alpha$-chain mutant. Can. J. Biochem. 48: 1066-1078.

42. Lorkin, P. A., D. Charlesworth, H. Lehmann, S. Rahbar, S. Tuchinda \& Lie INJo L. E. 1970. Two Haemoglobins Q, $\alpha 74$ (EF3) and $\alpha 75$ (EF4) Aspartic Acid $\rightarrow$ Histidine. Brit. J. Haematol. 19: 117-125.

43. Hyde, R. D., J. L. Kinderlerer, H. Lehmann \& M. D. Hall. 1971. Haemoglobin J Rajappen; a 90 (FG2) Lys $\rightarrow$ Thr. Biochem. Biophys. Acta 243: 515519.

44. Jenkins, T., K. Stevens, E. Gallo \& H. Lehmann. 1968. A second family possessing haemoglobin J $\alpha$-Capetown. S. African Med. J. 42: 1151-1154.

45. Charache, S., D. Weatherall \& J. Clegg. 1966. Polycythemia associated with a hemoglobinopathy. J. Clin. Invest. 45: 813.

46. Crookston, J. H., H. A. Farquharson, J. L. Kinderlerer \& H. Lehmann. 1970. Hemoglobin Manitoba: a 102(G9) serine replaced by arginine. Can. J. Biochem. 48: 911-914.

47. Stamatoyannopoulous, G., P. E. Nute, J. W. Adamson, A. J. Bellingham \& D. FUNK. 1973. Hemoglobin Olympia ( $\beta$ 20 Valine $\rightarrow$ Methionine): An Elec- 
trophoretically Silent Variant Associated with High Oxygen Affinity and Erythrocytosis J. Clin. Invest. 52: 342-349.

48. ENG, A. C., F. Vella \& C. C. Merry, 1970. Two possible instances of hemoglobin E Saskatoon in Manitoba. Can. J. Biochem. 48: 45-46.

49. RaHbar, S. 1973. Haemoglobin D Iran: $\alpha_{2} 22$ Glutamic Acid $\rightarrow$ Glutamine (B4). Brit. J. Haematol. 24: 31-35.

50. Bratu, V., P. A. Lorkin, H. Lehmann \& C. Predescu. 1971. Haemoglobin Bucuresti $\beta 42\left(C D_{1}\right)$ Phe $\rightarrow$ Leu, $A$ cause of unstable haemoglobin haemolytic anaemia. Biochem. Biophys. Acta 251: 1-6.

51. Konotey-Ahulu, F. I. D., J. L. Kinderlerer, H. Lehmann \& B. Ringelhann. 1971. Haemoglobin Osu-Christiansborg: A new $\beta$-chain variant of Haemoglobin A ( $\beta 52$ (D3) Aspartic Acid $\rightarrow$ Asparagine) in combination with Haemoglobin S. J. Med. Genet. 8: 302-305.

52. White, J. M., M. C. Brain, P. A. Lorkin, H. Lehmann \& M. SMrth. 1970. Mild "unstable haemoglobin haemolytic anaemia" caused by Haemoglobin Shepherds Bush ( $\beta 74$ ) (E18 Gly $\rightarrow$ Asp) Nature 225: 939-941.

53. Wajcman, H., D. Labie \& G. Schacira. 1973. Two new hemoglobin variants with deletion. Hemoglobins Tours: Thr $\beta 87$ (F3) deleted and Hemoglobin St Antoine: Gly-Leu $\beta$ 74-75 (E 18-19) deleted. Consequences for oxygen affinity and protein stability. Biochem. Biophys. Acta 295: 495-104.

54. AxsoY, M., et al. 1972. Hemoglobin Istanbul: Substitution of glutamine for histidine in a proximal histidine (F8(92)). J. Clin. Invest. 51: 2380-2387.

55. Fairananks, V. F., J. E. Maldonado, S. Charache \& S. H. Boyer, IV. 1971. Familial erythrocytosis due to electrophoretically undectable hemoglobin with impaired oxygen dissociation (Hemoglobin Malmö. $\alpha_{2} \beta_{3} 97$ Gln). Proc. Mayo Clin. 46: 722-728.

56. Koler, R. D., et al. 1973. Hemoglobin Casper. $\beta 106$ (G8) Leu $\rightarrow$ Pro. A contemporary mutation. Am. J. Med. 55: 549-558.

57. Flatz, G. J., L. Kinderlerer, J. V. Kilmartin \& H. Lehmann. 1971. Haemoglobin Tak: A variant with additional residues at the end of the $\beta$-chains. Lancet 1: 732-733.

58. Reed, R., W. P. Winter \& D. L. Rucknagel. 1973. Hemoglobin Inkster $85 \mathrm{Asp} \rightarrow \mathrm{Val} \mathrm{B}_{2}$

coexisting with $\beta$-thalassemia in a Caucasian Family. Brit. J. Haematol. 26: 465-484. 